\title{
METHOD OF FORMATION OF ENTREPRENEURIAL AND COMMUNICATIVE COMPETENCES OF FUTURE ACCOUNTANTS- ECONOMISTS IN THE PROCESS OF TEACHING OF PROFESSIONAL DISCIPLINES
}

ВОЛОДИМИР БАСАРАБ, кандидат педагогічних наук, методист, викладач, Богородчанський професійний будівельний ліцей, Украӥна

\section{МЕТОДИКА ФОРМУВАННЯ ПІДПРИЕМНИЦЬКОЇ ТА КОМУНІКАТИВНОЇ КОМПЕТЕНТНОСТЕЙ МАЙБУТНІХ БУХГАЛТЕРІВ-ЕКОНОМІСТІВ У ПРОЦЕСІ ВИКЛАДАННЯ ФАХОВИХ ДИСЦИПЛІн}

The author analyzes and characterizes the methods of formation of entrepreneurial and communicative competencies of future accountantseconomists. The basic forms and methods of conducting theoretical and practical classes are revealed. The method of formation of economic and communicative competencies of future accountants-economists is determined.

Key words: formation, competence, accountant, economist, methodology, classes, experience, knowledge, ability.

Анотація. У статті автором проаналізовано й охарактеризовано методи формування підприємницької та комунікативної компетентностей майбутніх бухгалтерів-економістів. Розкрито основні форми і методи проведення теоретичних і практичних занять. Визначено методику формування економічної та комунікативної компетентностей майбутніх бухгалтерів-економістів.

Ключові слова: формування, компетентність, бухгалтер, економіст, методика, заняття, досвід, знання, вміння.

Aim and objectives: clarification of the method of formation of entrepreneurial and communicative competencies of accountantseconomists during studying in higher education institutions.

Problem statement in general. In today's pedagogical literature, there is a tendency to develop methods and

(C) V. Basarab means of teaching that would meet the vocational education of the new model and the requirements of society and would most effectively promote the professional development of students in the educational process in higher education institutions. Such methods are widely used in the communication of new knowledge and, to a lesser extent, in the process of its consolidation. Their advantage is that a considerable amount of material can be reported in a relatively short time. Much attention in the educational process should be paid not to the mechanism of memorizing information, but to the achievement of its understanding, the ability to think logically, to use the knowledge and skills acquired in practice.

Analysis of research and publications. The works of domestic and foreign scientists in particular: L. Volkova; I. Ziazun, S. Kravets, N. Nichkalo, M. Levochko, M. Rostoki, L. Sushentseva, T. Furman, are devoted to the research of the problem.

Outline of the main research material. The analysis of approaches to understanding the scientific concept of "method" should begin with a revision of the material provided in the psycho-pedagogical encyclopedia. The term "method" is derived from the Greek word "methodos" which means the way, the path of moving towards the truth (Bulanova-Toporkova, 2002). Method - (from the Greek. methodos - the path to anything) means a method of activity aimed at achieving a certain goal (Method. URL : http://ua.textreferat.com/referat12529-1.html). The teaching method is considered as a way of work of the teacher and students by means of which the mastery of knowledge and skills is achieved, the world outlook is formed, abilities are developed (Kharlamov, 1990); the method is "a way of achieving a goal, a sort of orderly activity" (Philosofsky slovnyk, 1987).

Consequently, teaching methods teach students to solve individual cognitive tasks, to self-generalize the accumulated material, encourage professional activity, influence the quality of training of specialists.

The word, both as a source and a way of transmitting knowledge is common to all these methods, although each of them has its own peculiarities.

Fully sharing the idea that the effectiveness of verbal learning is possible only in combination with other types of work, it should be noted that without the "living" teacher's word the learning process can not be imagined. We endorse the opinion of $\mathrm{V}$. Sukhomlynsky, who wrote: "In the hands of a tutor, the word is as a powerful tool as a musical instrument in the hands of a musician, as paint in the hands of a painter, as a cutter and marble in the hands of a sculptor. There is no music without violin, no painting without paint and brush, no sculpture without cutter and marble, so there is no school and pedagogy without a lively, exciting word" (Sukhomlynsky, 
1976).

Thus, during the study of professional disciplines in particular, "Accounting", "Financial accounting", "Finance", "Economic diagnostics of the enterprise", "Audit", "Accounting policy", "Statistics", "Control system" in future accountants-economists are developing economic competence.

The experimental study confirms that the introduction of a system of active teaching methods, especially business games, provides an opportunity to link theoretical knowledge with the practical, which is the basis for the formation of economic competence of future accountantseconomists and allows to know and analyze their capabilities deeper.

In our opinion, the business game in the educational process involves highly organized cognitive, research, professional-productive, social activities.

The author O. O. Verbytsky noted that in the broadest sense, "business game" can be defined as a symbolic model of professional activity, the context of which is added by symbolic means - through the languages of modeling, imitation and communication, including natural language (Verbytsky, 1982).

As we can see in this definition, the practical side of the game participants' activity is not shown. O. V. Kozlov and M. L. Razu, defining the concept of "business game", highlight its quality as decision making for a specific situation in the conditions of step-bystep, multi-stage refinement of necessary factors, analysis of information that is additionally received and produced during the game (Kozlova \& Razu, 1978; Babkin \& Barkalov, 2001).

A distinctive feature of a business game is the modeling of the content of the game and the process of a future professional activity and the system of their relations within the given model of a real production team by participants. Thus, business game is one of the means of modeling of the professional activity in the educational process, the essence of which is to reproduce this activity in specially created conditions that reflect the real situation.

Adhering to this point of view, $\mathrm{O}$. V. Shmakova notes that the business game should be understood as an important model that reproduces the processes of decision-making and interaction of participants in management systems. In these lessons, students play the role of different specialists in the game manner, acquiring new knowledge, as well as demonstrate their knowledge of the theory and at the same time reinforce their practical experience.

As you know, business game refers to active learning methods. It is a high level of manifestation of cognitive and independent types of learning and is of great importance in the training of economists, accountants and accountants for industries and sectors of the economy. Studying the experience of using educational games requires answering the following questions:

- what is positive about this experience?

- what is negative?

- what should be considered in the future?

You can create a certain idea about the effectiveness of the game by questioning its members. The analysis of students' questionnaires shows that the game teaches to apply knowledge in practice, develops creative abilities, fosters a sense of collectivism, increases interest in future work and confidence in the right choice of a profession. Students mark the game day as one of the best.

In order to increase the effectiveness of educational games, it is necessary not to copy the real economic situation, but to reproduce the basic links that students should discover, understand and use. Business game is a form of learning, it can perform various functions.

In order to conduct a business game, you need to develop several steps: setting the purpose and objectives of the game; writing a scenario with the definition of actors; selection of practical material; development of general and individual initial data and tasks for the participants of the game; definition of criteria for evaluation of results.

The widespread use of business games can reduce learning time by 30 $65 \%$. Basic business game development is the product of a simulation and game model that should organically overlap, which determines the structure of the business game.

In the process of formation of economic competence of future accountants-economists, we will introduce in the educational process only those stages of the game, which are related to professional disciplines. We have developed several plans (guidelines) for playing games and didactic games for students of higher education institutions. At the meetings of the department the topic of conducting a business game were considered, discussed and approved as a methodical development and invention.

Personal experience of using business games has shown that business games allow students to practice the type of economic activity in dynamics; during the game, not only the teachers but also the students themselves can more objectively evaluate the level of mastering the educational material; the economic thinking is developing; the game allows for 1 class to test and build on students' knowledge of the topic.

Noteworthy is the study of G. N. Nazarenkova in the field of methodology of using business game as a method of programming roles. The author of this study relies on the value of a business game as a game modeling of fragments of a specific reality - "The game should reflect the essential connections and attitudes of the educational process."

However, it is not only during the training in professional disciplines that you can use game forms of learning organization. We offer a role-playing game that is advisable to do during the "Financial accounting" practical classes.

In the example of one of the training laboratories in the game process, accounting is simulated. Such a game will help to prepare specialists of certain links for the accomplishing the task and making alternative decisions. In the course of work, control over the implementation of the decisions made is carried out and, if necessary, correction of actions takes place, timely agreed decisions are made, aimed at eliminating minor errors, etc.

In the first stage of the game (preparatory), the teacher introduces the structure, content and purpose of the game, as well as the functional responsibilities of its participants. Then students are offered to divide into game groups by number of roles, to choose chief accountants. In the second stage (game) participants prepare for work in accounting, analyzing the situation, make the necessary calculations, develop 
variants of their proposals, substantiate them and conduct the game. The chief accountant monitors the reports of accountants and recorders on the progress of work, on the decisions made, summarizes the information, submits proposals that are actively discussed by all participants, and then the final decision. In the third stage of the game (final), the team members determine the ways of equipping the workplaces, the optimal organization of their work for the daily task. After that, tax and auditors summarize, evaluate the performance of groups, record successes and mistakes, identify personal and team positions.

Thus, in the process of collective game activity is the social development of the individual. Students participants of the game develop practical skills in the work community, acquire experience of management, leadership and team organization, develop the skills of complex creative problem solving. The beliefs which constitute the outlook are formed, a creative approach to the fulfillment of future professional functions is developed on the basis of knowledge and skills.

Consider the use of crossword puzzles in accounting theory. They are created with one or more section topics. The method of working with them comes down to their decision in class. For example, students are given a ready-made drawing of a crossword puzzle and the terms of its solution. On the board we hang a big crossword puzzle. Team members, with the permission of the captains, go out to the board and put the letters in the appropriate cells. Team captains and a teacher keep records of the number of points each participant has scored and grade. The work can be organized as a team competition. To award appropriate places, the number of points scored by each team is counted, the most active players and the work of captains are noted. Accounting crossword puzzles can be offered as an independent job. When selecting words that are relevant to a particular accounting concept, there is a process of thinking, reviewing the "baggage" of knowledge that has been learned in previous topics or disciplines. Crossword puzzles can be created not only at the information level but also at the problem level. This is not only forces students to remember what they have learned, but also to understand the content of the problem, to understand its essence more effectively. In this regard, solving and creating crossword puzzles is seen as an element of game and problem learning.

Now let's turn to the value, characterization and conduct of accounting dictation. It is created in a such way that in 8-12 sentences the most important tasks, rules, provisions of the educational material are highlighted. Students are offered to complete new information during the course - formulas, numbers, words, definitions. For example, on the topic: "Classification of accounts and their value in accounting" the following dictation may be suggested: active accounts I know: (fixed assets, cash, current bank accounts, production, finished products, etc.); what is the formula of these accounts?; active passive accounts include: (sales revenue, retained earnings, uncovered losses); authorized capital is..: these are the answers students should write quickly under the dictation of the teacher.

Thus, in the process of collective game activity is the social development of the individual. Students participants of the game develop practical skills in the work community, acquire experience of management, leadership and team organization, develop the skills of complex creative problem solving. On the basis of knowledge and skills beliefs which constitute the outlook are formed, , a creative approach to the fulfillment of future professional functions is developed. In turn, such disciplines as "Micro-macroeconomics", "Political Economy" "Fundamentals of Business", "Enterprise Economics", "Marketing", "Management" form a communicative competence. Each science operates with the relevant concepts, which accumulate and concentrate its knowledge. In this regard, each discipline requires the selection of new scientific concepts specific to the particular discipline (for example, accounting: debit, credit, account, balance, register, accounting correspondence, etc.).

It should be noted that educational discussions also take place on the formation of communicative competence - (from Latin discussio review, research). They are based on the exchange of opinions between students, teachers, they teach to think independently, develop the capacity for reasoned argument, and economic thinking is formed. It is desirable that the discussions should not be in the form of "student's question - teacher's response", but to show students' skills. In the process of analyzing the study, we came to the conclusion that the most effective discussions are with the participation of specialists economists, accountants, financiers, auditors, bankers, scientists. That is why we try to invite practitioners from different institutions or enterprises to study in the field of economics. In our opinion, the main function of the discussion is to stimulate cognitive interest of students.

A. M. Boyko attaches the great importance to dialogue throughout the whole educational process, confirming that the result of such a teaching method is the development of the creative abilities of the individual. The ability to build a dialogue according to the didactic goals of the lesson is a significant characteristic of the teacher's personality.

One of the main functions of teaching, in particular, is a problematic lecture, which encourages students to creative thinking and their creative approach to organizing their own learning activities and evaluating their results. During such lectures it is appropriate to use problematic questions, tasks, production situations. Please note that course study should not be started immediately with lectures with problematic tasks. Students first need to learn how to "see" or "feel" a problem, to find the answer to a problematic question, is to understand the essence of the problem.

A better understanding and assimilation of theoretical material by future accountants seems to be facilitated by the use of a variety of learning resources. It is advisable to use diagrams, posters, a projector, display real accounting documents, electronic presentations, etc. in the professional disciplines.

A problem question is smaller than a problem task, so there are several that you can use during a lecture. In the process of searching for answers to problematic questions, it is advisable to establish a dialogue with students, during which the teacher will be able to direct their thoughts on finding and highlighting the learning problem. In this way, the students' knowledge they used to find ways to solve the problem are activated, systematized and 
summarized. For example, when studying the subject "Balance sheet of the enterprise" in the discipline "Accounting" so that future the accountants-economists understand the theoretical material better a teacher is recommended before explaining the structure of the balance sheet to ask the question: "What do you think affects the life balance of a person?" This will allow students to update knowledge from previous theoretical material, and the teacher to make logical connections between students' theoretical knowledge. Thus, future accountants-economists create associations that in the future will contribute to a better reproduction of theoretical knowledge.

It should be noted that also practical work influences on the formation of communicative competencies of future accountantseconomists, it is used to acquire and consolidate knowledge, promote the connection of theory with practice, form skills in using computers, learn to process the results obtained in accounting, economics and statistics, make the right conclusions and suggestions. In practical classes, students learn about issues related to their professional activities. Practical classes we associate with theory, they can be in writing (tests) and oral (report, press conference, defense of abstracts) forms.

Practical classes in the discipline "Accounting" are recommended to conduct in the form of a business game. Each student has the opportunity to be an accountant and perform his duties. Other students in the class play the role of participants. After a fragment of the lesson, the effectiveness of the proposed methodology is discussed. Such classes are difficult to carry out, but they bring students closer to the real conditions of the educational process of training specialists in economic profile and have a positive impact on their future professional adaptation.

The purpose of practical classes in professional disciplines is to broaden the ideas of future accountantseconomists about the method and principles of accounting, to prepare the accounting statements, to make calculations, the formation of skills to detect errors and the ability to eliminate them, mastering the future accountants-economists with the professional skills required not only in training but also in production.

Therefore, practical work is a student's professional activity aimed at mastering practical skills and work skills. The content of the work should reflect the tasks related to future professional activity (Babkin \& Barkalov, 2001). It should be noted that teachers of professional disciplines, when developing the topics and content of practical classes, should take into account their place in the professional training of future accountants-economists.

Equally important in the formation of communicative competence in future accountants-economists and interesting for them is the solution of production situations and tasks. According to G. Krasylnykova, the production situation is one of the effective forms of collegial solution of complex production tasks, it allows to assess the situation in a qualified and comprehensive manner (Красильникова, URL : http://lubbook.net/ book_303_glava_17_Tema_15.). Production situations contribute to the formation of students' communicative thinking and the development of their knowledge needs. Students are faced with the need to choose from the available knowledge of the only correct system, the use of which can provide the correct solution to the proposed problem. For conducting classes and organizing control over independent work, we have developed economic situations on the topics: "Accounting for cash", "Accounting for labor and wages", "Accounting for inventories", "Accounting for fixed assets". Higher education institutions also use situational professional tasks. These are typical production tasks that characterize the industries, production, where future specialists will work. Accounting is a cross-cutting task that includes all the major operations sequentially mastered in the accounting system. Each student receives certain initial data (tasks are given individually), which he replenishes as the study of theoretical material. The task covers the following accounting operations: fixed assets, inventories, LVIS, wages, commodity operations, settlement and credit operations, financial results of activities.

We suggest when studying the topic "Accident Insurance" in the discipline "Finance" at the stage of motivation of cognitive activity of students, to use the following problematic situation: "It's winter, a woman goes to work, the road is icy, and she falles and brake her leg. The man walks past her and asks what happened, and she replies that she has an accident. And he asks if she is insured? Give an assessment of the situation." The victim replied that she was not insured, accordingly no insurance reimbursement will be made. Therefore, all employees should understand that if they are formalized, then their wages are deducted into the appropriate fund from which the disability payment will be made. After discussing the situation, the teacher summarizes: "So, according to a certain situation, you will know that you need to be insured in order to have financial support after the accident."

Throughout the study of the discipline of "Accounting" students keep a record and record transactions in the same accounting books, which forms in them the ability to navigate in different accounting documents. It is important to emphasize that the performance of such tasks provides a consistent transition from mastering professional skills to self-fulfilling of professional functions, enables students to really understand the cross-curricular relationships and their importance in professional activity.

For successful formation of communicative competence in future accountants-economists during lectures, practical classes in professional disciplines it is recommended to create conditions for realization of creative activity of students.

Also, the formation of communicative competence of the future accountant is facilitated by interactive learning technologies. They need clarification, taking into account the specifics of economic direction. According to "Modern Dictionary of Foreign Language Words", interactive (English interaction - cooperation, common action) - dialog (Skopenko \& Tsymbalyuk, 2006). So interactive is capable of cooperation, dialogue, interpersonal interaction.

The basic techniques and methods used in interactive learning and providing subject-subject interaction between teachers and students are not entirely new to the national education system.

Research from the National Training Center (1980s, USA) shows that the greatest results can be achieved 
through interactive learning (discussion groups - 50\%, practice through action $-75 \%$, teaching others or the immediate application of knowledge $-90 \%$ ), and the smallest in terms of passive learning (lecture 5\%, reading - 10\%) (Yermakov, 2005, c. 423). Interactive learning provides a sharp increase in the percentage of students learning the material, because it affects not only consciousness but also self-consciousness and subconsciousness, positively affects the emotional-volitional sphere of the psyche.

Exploring the problem of interactive learning, a group of scientists led by O. Pometun and L. Pyrozhenko, define it as a special form of organization of cognitive activity, which has a specific, intended purpose - to create comfortable learning conditions in which each student feels his success, intellectual ability (Pometun, Pyrozhenko \& Kobernyk, 2004, c. 4).

The views of a scientist should be considered progressive and it should be summarized that interactive learning is a set of certain methods, techniques, forms and means of organizing the educational process, aimed at achieving the goal of learning, as well as to create comfortable conditions for subject-subject interaction. In addition to enhancing intellectual processes, such training should foster the formation of an experience and culture of interpersonal interaction that has a positive impact on the success of future accountants-economists. Therefore, in the process of student preparation, it is recommended to make extensive use of interactive methods, including the problematic ones that underlie problem learning.

Conclusions from the study and prospects for further exploration in this area. The proposed methodology for the formation of entrepreneurial and communicative competencies of future accountants-economists is implemented through the use of methods, tools and forms of organization of training of professional disciplines, as well as through the organization and conduct of excursions, production practice and business games. Business and roleplaying games effectively reproduce the overall tasks of an accountant in a particular position. They contribute to the future accountant-economist's professional experience; accumulation of knowledge on the analysis of professional tasks and management decisions.

A prospective direction for further exploration is to determine the method of formation of legal competence of future accountants-economists.

\section{REFERENCES}

Bulanova-Toporkova, M. V. (2002). Pedagogika i psihologiya vycshei shkoly. Rostov na Donu: Pheniks Publ.

Method [Electronic resource]. Available at: http://ua.textreferat.com/ referat-12529-1.html

Kharlamov, N. F. (1990). Pedagogika. Moscow : Vysshaya shkola Publ.

Philosofsky slovnyk. (1987). Moscow : Pedagogy Publ.

Sukhomlynsky, V. O. (1976). Vybrani tvory. Kyiv : Rad.shkola Publ.

Verbytsky, A. A. (1982). Delovaya igra kak metod aktivnogo obucheniya. Vestnik vysshei shkoly Publ., 3, 129142.

Kozlova, O. V. \& Razu, M. L. (1978).

Delovyie igry i ih rol $\mathrm{v}$ povyshenii kvalifikatsyi kadrov. Moscow : Znaniye Publ.

Babkin, V. F. \& Barkalov, S. A.(2001). Modeli, metody i mekhanizmy povysheniya effectivnosti uchebnogo processa. Moscow.

Krasylnykova H. V. Profesiina pedagogika. URL : http://lubbook.net/ book_303_glava_17_Tema_15.

Suchasny s-ovnyk inshmovnyh sliv. (2006). Kyiv : Dovira Publ.

Yermakov, I. G. (2005). Zhyttyeva kompetentnist osobystosti: vid teorii do praktyky. Zaporizhzhya: Centrion Publ.

Pometun O. I., Pyrozhenko L. V. \& Kobernyk H. I. (2004). Interaktyvni tekholohii navchannya. Kyiv: Nauk. Svit Publ.

\section{СПИСОК ЛІТЕРАТУРИ}

Буланова-Топоркова, М. В. (2002). Педагогика и психология высшей школы. Ростов н/Д. : Феникс.

Метод. URL : http:// ua.textreferat.com/referat-125291.html

Харламов, Н. Ф. (1990). Педагогика. Москва : Высшая школа.

Філософський словник. (1987).

Москва : Педагогіка.

Сухомлинський, В. О. (1976).

Вибрані твори. Київ : Рад. школа.

Вербицкий, А. А. (1982). Деловая игра как метод активного обучения. Вестник высшей школы, 3, 129-142.

Козлова, О. В. \& Разу, М. Л. (1978). Деловые игры и их роль в повышении квалификации кадров. Москва : Знание.

Бабкин, В. Ф. \& Баркалов С. А. (2001). Модели, методы и механизмы повышения эффективности учебного процесса. Москва.

Красильникова, Г. В. Професійна педагогіка. URL : http:// $\begin{array}{lllllllllllll} & \mathrm{u} & \mathrm{b} & \mathrm{b} & \mathrm{o} & \mathrm{o} & \mathrm{k} & \text {. } & \mathrm{n} & \mathrm{e} & \mathrm{t} & \text { / }\end{array}$ book_303_glava_17_Tema_15.

Сучасний словник іншомовних слів. (2006). Київ : Довіра.

Життєва компетентність особистості: від теорії до практики. (Ред. Срмакова, I. Г.). (2005). Запоріжжя : Центріон.

Пометун, О. І., Пироженко, Л. В. \& Коберник, Г. І. (2004). Інтерактивні технології навчання. Київ : Наук. світ.

Стаття надійшла 7.12.2019 p. 